\title{
Enzymatic Hydrolysis of Whey Protein Concentrates: Peptide HPLC Profiles
}

\author{
M. V. T. Mota, ${ }^{1}$ I. M. P. L. V. O. Ferreira, ${ }^{1, *}$ \\ M. B. P. Oliveira, ${ }^{1}$ C. Rocha, ${ }^{2}$ J. A. Teixeira, ${ }^{3}$ \\ D. Torres, ${ }^{4}$ and M. P. Gonçalves ${ }^{4}$ \\ ${ }^{1}$ REQUIMTE, Serviço de Bromatologia, Faculdade de Farmácia, \\ Universidade do Porto, Porto, Portugal \\ ${ }^{2}$ Escola Superior de Tecnologia e Gestão, Instituto Politécnico de Viana \\ do Castelo, Viana do Castelo, Portugal \\ ${ }^{3}$ Centro de Engenharia Biológica-IBQF, Universidade do Minho, \\ Braga, Portugal \\ ${ }^{4}$ REQUIMTE, Departamento de Engenharia Química, Faculdade de \\ Engenharia, Universidade do Porto, Porto, Portugal
}

\begin{abstract}
Hydrolysis of whey protein concentrates (WPCs) at different temperatures and $\mathrm{pHs}$, using three enzymes: pepsin, trypsin, and Alcalase ${ }^{\circledR}$, was monitored during more than $5 \mathrm{hr}$ by reversed phase HPLC/UV,
\end{abstract}

*Correspondence: I. M. P. L. V. O. Ferreira, REQUIMTE, Serviço de Bromatologia, Faculdade de Farmácia, Universidade do Porto, Rua Aníbal Cunha, 164, 4050-047 Porto, Portugal; E-mail: isabel.ferreira@ff.up.pt. 
using a column containing a polystyrene-divinylbenzene copolymer-based packing, and an elution gradient from $8 \%$ to $80 \%$ acetonitrile containing $0.1 \%$ TFA. Peptides were separated according to their polarity and size, and degradation of $\alpha$-lactalbumin ( $\alpha$-la) and $\beta$-lactoglobulin $(\beta-\lg )$ was evaluated. The three proteolytic enzymes (pepsin, trypsin, and Alcalase ${ }^{\circledR}$ ) employed for hydrolysis of WPCs led to different kinetics of degradation of $\beta$-lg. $\alpha$-la degradation after 15 min was almost complete for the three enzymes. The hydrolysis catalysed by each enzyme resulted in different peptide profiles by HPLC/UV. Hydrolysates produced by pepsin (HP) were resolved into three main fractions of high retention times, while tripsin hydrolysates (HT) were resolved into nine major peaks and Alcalase ${ }^{\circledR}$ hydrolysates (HA) were resolved into 12 major peaks, presenting a wide range of polarities and sizes. Although, with different $\beta$-lg hydrolysis extension, chromatographic profiles of the degradation and formation of peptides can be used as a finger print of the type of enzyme used, because peptide profile is not affected either by temperature or $\mathrm{pH}$.

Key Words: Whey proteins; Enzymatic hydrolysis; RP-HPLC.

\section{INTRODUCTION}

The concepts in nutrition have changed significantly over the last decade. Apart from nutritional effects, food can also have a health-promoting potential, reducing the risk of diseases, i.e., functional foods ${ }^{[1]}$ Their functionality is based on the presence of bioactive components or is connected with food processing. In fact, food components with determined properties can be used to obtain a product with the design characteristics.

Major whey protein components, $\alpha$-lactalbumin ( $\alpha$-la) and $\beta$-lactoglobulin $(\beta-\lg )$, are an important source of bioactive sequences. Whey hydrolysates showed ACE-inhibitory activity after proteolysis with different digestive enzymes, and several active peptides were identified. ${ }^{[2-5]}$ From a dietary point of view, protein hydrolysates can also be used to, e.g., reduce allergenicity or improve digestability of foodstuffs. ${ }^{[6]}$ In any case, it has been shown that protein hydrolysates should be rich in low molecular weight peptides which offers advantages for dietary purposes. ${ }^{[6]}$ Depending on the type of product in which peptides will be incorporated, the degree of hydrolysis required is different. ${ }^{[7]}$

So far, the most common way to produce bioactive peptides has been through enzymatic digestion. Pancreatic enzymes, preferably trypsin, have been used for identification of many known bioactive peptides. ${ }^{[5]}$ However, 
other enzymes, including Alcalase ${ }^{\circledR}$ and pepsin, have also been used to generate bioactive peptides. ${ }^{[8-11]}$

The present study was undertaken in order to (i) determine the extent of degradation of native whey proteins ( $\beta$-lg and $\alpha$-la) by three enzymes, pepsin, trypsin, and Alcalase ${ }^{\circledR}$ and (ii) evaluate whether the chromatographic profile obtained was affected by temperature and $\mathrm{pH}$ conditions of the environment or only dependent on enzyme type.

With this objective, an RP-HPLC/UV method was used to follow the time course of the degradation of the native whey proteins and the formation of peptides, which were separated according to their polarity. RP-HPLC was performed on a column, containing a polystyrene-divinylbenzene copolymerbased packing, using an elution gradient from $8 \%$ to $80 \%$ acetonitrile, containing $0.1 \%$ TFA. Studies were performed at different temperatures and $\mathrm{pH}$, and monitoring was carried out during more than $5 \mathrm{hr}$.

\section{EXPERIMENTAL}

\section{Substrate and Enzymes}

A commercial spray dried whey protein concentrate (WPC) with $80 \mathrm{wt} \%$ of protein was used as substrate.

Pepsin from porcine gastric mucosa, with an activity of 975 units $/ \mathrm{mg}$ protein, trypsin from porcine pancreas with an activity of 1020 BAEE units $/ \mathrm{mg}$ protein, and protease from Bacillus licheniformis (Alcalase ${ }^{\circledR}$ ) with an activity of $2.77 \mathrm{AU} / \mathrm{mg}$ protein, were obtained from Sigma Chemical Co.

\section{Hydrolysis}

Enzymatic hydrolysis was performed in a $0.5 \mathrm{~L}$ stirred, tank-type, batch reactor equipped with $\mathrm{pH}$ and temperature control.

The three enzymes were used in several experiments where the influence of $\mathrm{pH}$ or temperature was analysed. The values of these two parameters for each experiment, with each of the enzymes, are presented in Table 1.

For each experiment, samples were collected, before (time zero) and during the hydrolysis of bovine milk WPC, at variable intervals of time, during more than $5 \mathrm{hr}$. After this period of time, the reaction was stopped either by immersion of the samples in a water bath at $90^{\circ} \mathrm{C}$ (for trypsin and Alcalase ${ }^{\circledR}$ ) or by adding Tris- $\mathrm{HCl}$ buffer at $\mathrm{pH} 7$ (for pepsin). All the samples were stored at $-20^{\circ} \mathrm{C}$. Prior to analysis by RP-HPLC, samples were left at room temperature and diluted with ultra purified water. 
Table 1. Values of $\mathrm{pH}$ and temperature for each experiment with the enzymes under study.

\begin{tabular}{|c|c|c|c|c|c|}
\hline \multicolumn{2}{|c|}{ Pepsin } & \multicolumn{2}{|c|}{ Trypsin } & \multicolumn{2}{|c|}{ Alcalase ${ }^{\circledR}$} \\
\hline$T\left({ }^{\circ} \mathrm{C}\right)$ & $\mathrm{pH}$ & $T\left({ }^{\circ} \mathrm{C}\right)$ & $\mathrm{pH}$ & $T\left({ }^{\circ} \mathrm{C}\right)$ & $\mathrm{pH}$ \\
\hline & 1 & & & & \\
\hline & 2 & & 8 & & 7 \\
\hline \multirow[t]{2}{*}{37} & 3 & 37 & 9 & 37 & 8 \\
\hline & 4 & & & & 9 \\
\hline 30 & & & & 30 & \\
\hline 37 & 2 & 37 & 8 & 37 & 8 \\
\hline 40 & & 50 & & 50 & \\
\hline
\end{tabular}

\section{Reagents and Protein Standards}

All reagents used were of analytical grade purity. Solvents for HPLC were filtered through $0.22 \mu \mathrm{m}$ NL 17 filters and degassed under vacuum for at least 15 min before use.

Purified bovine standards of $\beta$-lg and $\alpha$-la were supplied by Sigma Chemical Co. and dissolved in ultra purified water.

\section{HPLC Separation}

\section{Instrumentation}

The chromatographic analysis was carried out in an analytical HPLC unit (Jasco) equipped with two type PU-980 pumps, a type UV-970 detector, and a type 7125 Rheodyne Injector with a $20 \mu \mathrm{L}$ loop.

The column was a reversed-phase column Chrompack P 300 RP, that contains a polystyrene-divinylbenzene copolymer-based packing $(8 \mu \mathrm{m}, 300 \AA$, $150 \times 4.6 \mathrm{~mm}^{2}$ i.d. $)$. A Chrompack P RP $\left(24 \times 4.6 \mathrm{~mm}^{2}\right.$ i.d. $)$ was used as a pre-column.

\section{Separation Conditions}

Gradient elution was carried out with a mixture of two solvents. Solvent A: $0.1 \%$ trifluoroacetic acid (TFA) in water and solvent B: $0.1 \%$ TFA in $80 \%$ aqueous acetonitrile, $(\mathrm{v} / \mathrm{v})$. Proteins and peptides were eluted 
as follows: $0-1 \mathrm{~min}, 90 \% \mathrm{~A} ; 1-10 \mathrm{~min}, 90-80 \% \mathrm{~A} ; 10-15 \mathrm{~min}, 80-75 \% \mathrm{~A}$; 15-20 min, 75-60\% A; 20-30 min, 60-50\% A; 30-33 min, 50-40\% A; 33-36 $\mathrm{min}, 40-30 \% \mathrm{~A} ; 36-39 \mathrm{~min}, 30-20 \%$ A; 39-41 $\mathrm{min}, 20-0 \% \mathrm{~A}$, returning to initial conditions in $9 \mathrm{~min}$.

The flow-rate was $0.5 \mathrm{~mL} / \mathrm{min}$. The column was used at ambient temperature and detection at $215 \mathrm{~nm}$. Total run time was $50 \mathrm{~min}$.

\section{RESULTS AND DISCUSSION}

\section{Separation of $\beta$-lg and $\alpha$-la of Bovine Whey}

The HPLC conditions were optimised, at room temperature, for mobile phase composition, gradient, and flow-rate in order to obtain the best separation of peptides from whey proteins hydrolysates. Under the conditions adopted, the $\alpha$-la and $\beta$-lg fractions were well separated and exhibited the retention times of 34.5 and $37.5 \mathrm{~min}$, respectively. The chromatographic system was calibrated by the external standard method with solutions that contained bovine $\alpha$-la in the range of $0.039-1.0 \mathrm{mg} / \mathrm{mL}$ and bovine $\beta$-lg in the range of $0.004-1.0 \mathrm{mg} / \mathrm{mL}$. A linear relationship between the concentrations of bovine $\alpha$-la and $\beta$-lg and the UV absorbance at $215 \mathrm{~nm}$ was obtained (Table 2). Detection limit calculated as three times the background noise was $0.01 \mathrm{mg} / \mathrm{mL}$ for $\alpha$-la and $0.002 \mathrm{mg} / \mathrm{mL}$ for $\beta$-lg.

The precision of the method was measured by analysing six injections of

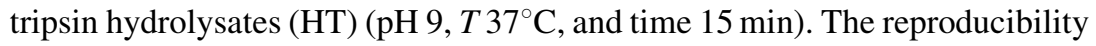
of peak areas was good. RSD ranged between $1.9 \%$ and $9.2 \%$.

\section{Pepsin Degradation of Whey Proteins and Peptide Formation}

Reversed-phase HPLC was used to follow pepsin-catalysed degradation

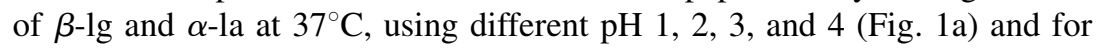
$\mathrm{pH} 2$, at different temperatures $30^{\circ} \mathrm{C}, 37^{\circ} \mathrm{C}$, and $40^{\circ} \mathrm{C}$ (Fig. 1b).

Table 2. Calibration curves determined by the external standard method.

\begin{tabular}{lccccc}
\hline & $\begin{array}{c}\text { Concentration } \\
\text { range }(\mathrm{mg} / \mathrm{mL})\end{array}$ & $\begin{array}{c}\text { Slope (area } \\
\text { counts } / \mathrm{mg})\end{array}$ & $\begin{array}{c}\text { Intercept } \\
\text { (area counts) }\end{array}$ & $r^{\mathrm{a}}$ & $\begin{array}{c}\text { Detection } \\
\text { limit }(\mathrm{mg} / \mathrm{mL})\end{array}$ \\
\hline$\alpha$-la & $0.039-1.0$ & $3.0 \times 10^{7}$ & $7 \times 10^{6}$ & 0.9953 & 0.010 \\
$\beta-\lg$ & $0.004-1.0$ & $3.0 \times 10^{7}$ & $5 \times 10^{6}$ & 0.9949 & 0.002 \\
\hline
\end{tabular}

${ }^{\mathrm{a}}$ Correlation coefficient. 

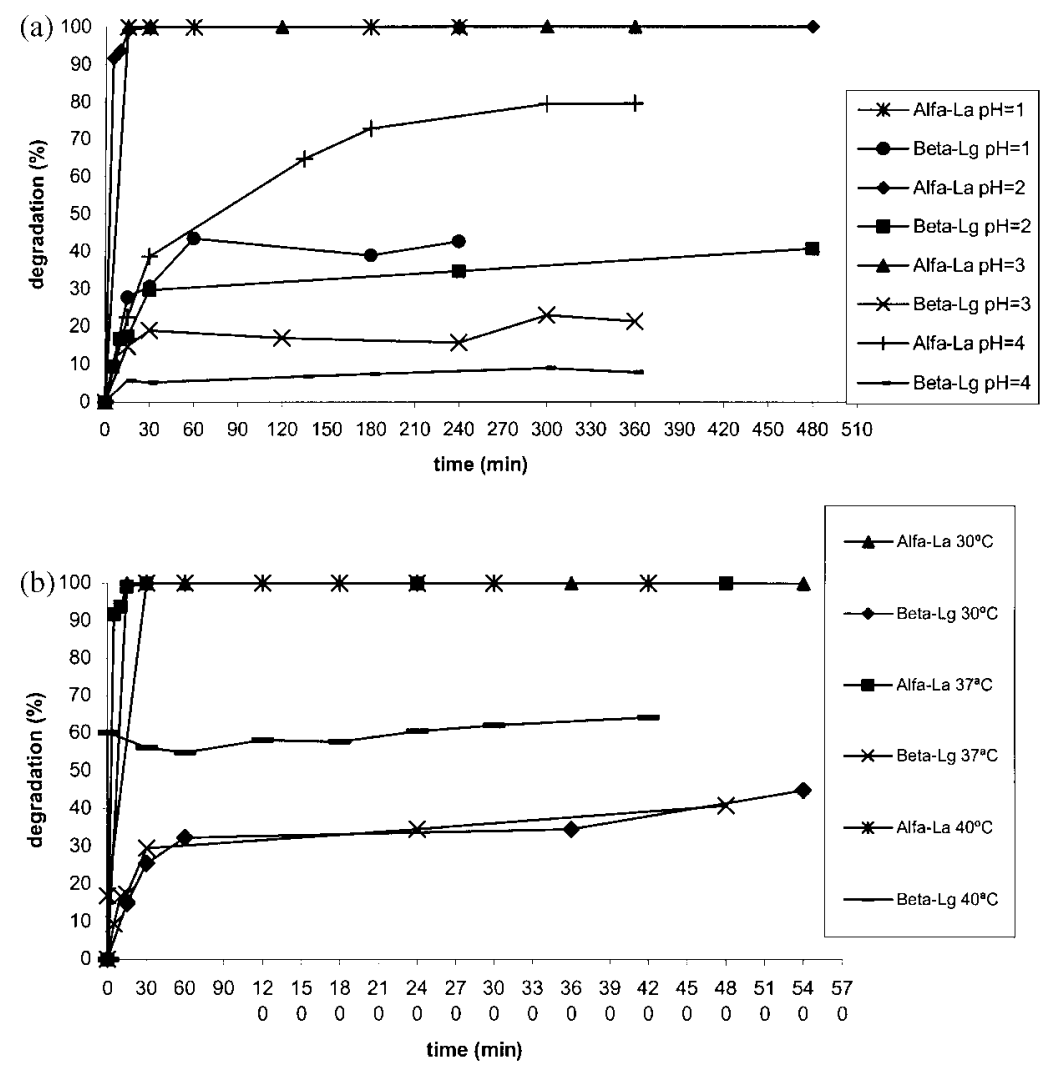

Figure 1. (a) Evolution of $\beta-\lg$ and $\alpha$-la degradation during pepsin hydrolysis at $37^{\circ} \mathrm{C}, \mathrm{pH}=1,2,3$, and 4 ; (b) $\mathrm{pH} 2$ at $30^{\circ} \mathrm{C}, 37^{\circ} \mathrm{C}$, and $40^{\circ} \mathrm{C}$.

Pepsin was able to hydrolyse $\beta$-lg and $\alpha$-la at $37^{\circ} \mathrm{C}$ under the conditions used. $\alpha$-la degradation after 15 min was almost complete, except for $\mathrm{pH} 4$; at this $\mathrm{pH}$ only about $22.4 \%$ of the original $\alpha$-la degraded in $15 \mathrm{~min}$ (Fig. 1a). Pepsin degraded $\beta$-lg more slowly, leaving about $40 \%$ intact after $480 \mathrm{~min}$ of incubation at $\mathrm{pH} 2$. This is in accordance with the results obtained by others, ${ }^{[11]}$ indicating that native $\beta-\lg$ is a poor substrate for pepsin. Degradation of $\beta$-lg increased with $\mathrm{pH}$ decrease (Fig. 1a).

Similar degradation of $\beta$-lg was obtained at $30^{\circ} \mathrm{C}$ and $37^{\circ} \mathrm{C}$. However, increasing temperature to $40^{\circ} \mathrm{C}$ degradation of $\beta$-lg increased twice (Fig. 1b).

Chromatograms of Pepsin hydrolysates (HP) displayed a large peak with retention time around $25 \mathrm{~min}$ in addition to the intact $\beta$ - $\lg$ and two other small peaks. The retention times for these three peaks/fractions, 
designated P1, P2, and P3 in order of increasing times, were 16.7, 21.0, and 25.5, respectively (Fig. 2). The appearance of peptide products was followed as a function of time. Changes in the relative areas of the fractions with time are shown in Fig. $3 a$ and $b$; peak areas are given in percent of peak area of initial $\beta$-lg.

Hydrolysis resulted in the formation of large fragments as judged from the high retention time of fraction P3 and its heterogeneous aspect (Fig. 3a). Once these fragments were released, the susceptible peptide bonds they contained became accessible, resulting in further degradation into P1 and P2 fractions, with lower retention times. This interpretation is in agreement with other works. ${ }^{[11]}$ After 240 min, the proportion of P3 decreased, P1 and P2 increased very slowly.

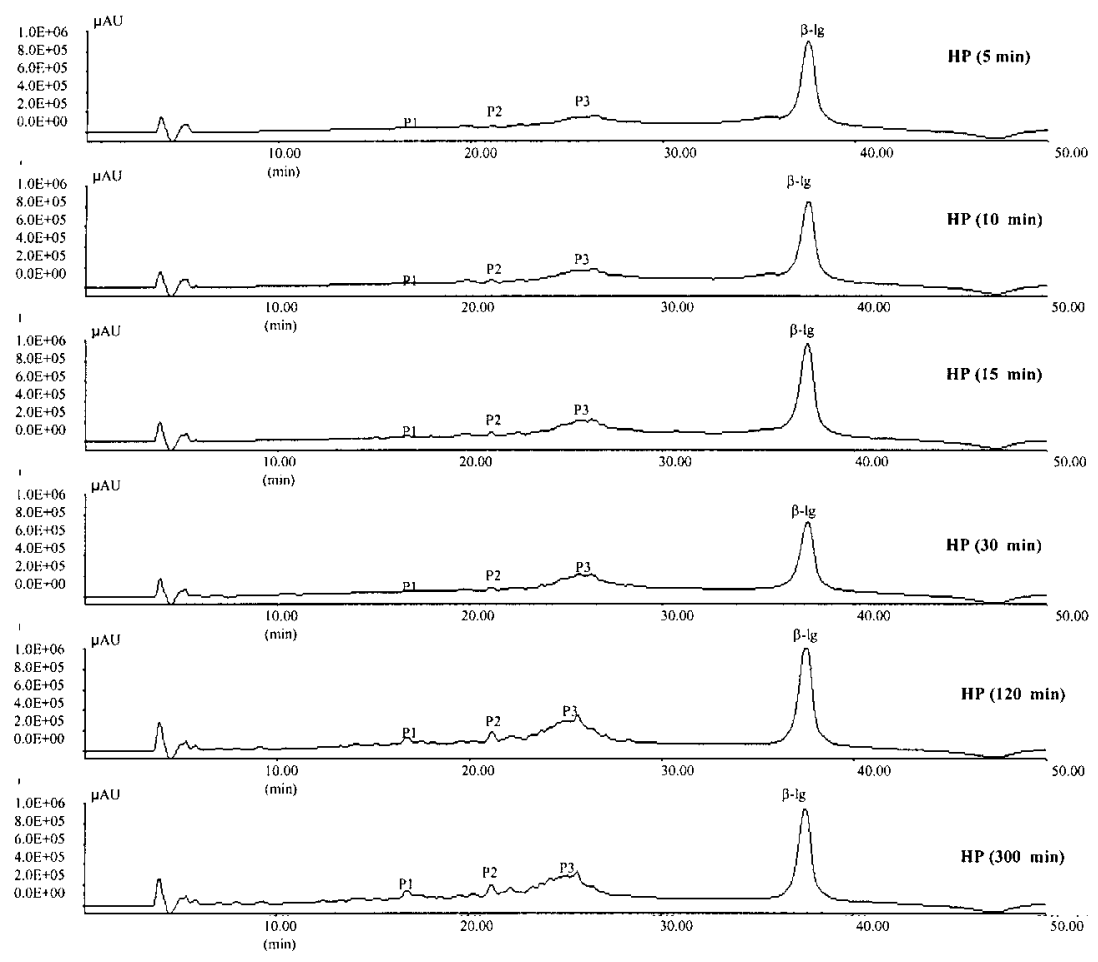

Figure 2. Typical HPLC profiles of $\mathrm{HP}\left(T=37^{\circ} \mathrm{C} ; \mathrm{pH}=2 ; 5 \mathrm{hr}\right.$ hydrolysis time $)$. Three major fractions were designated P1, P2, and P3 according to the order of increasing retention times. 

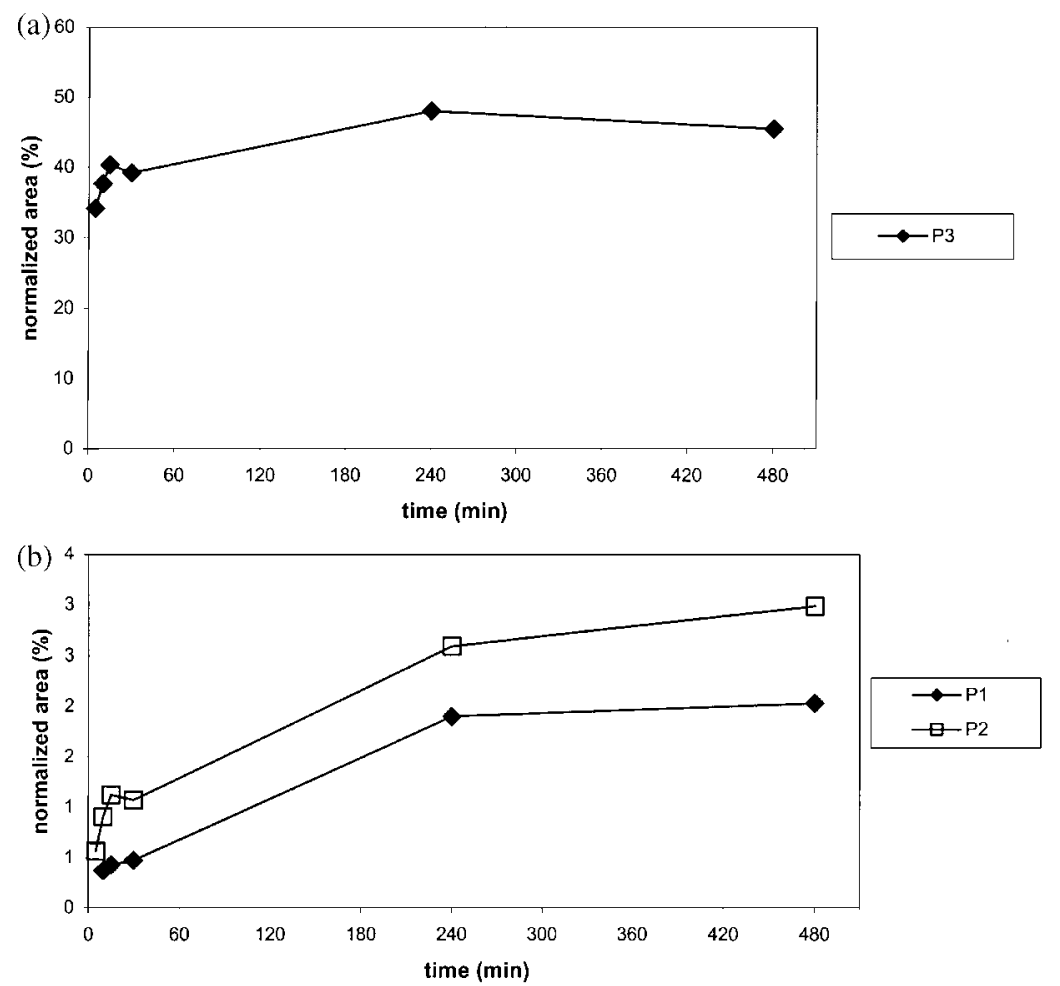

Figure 3. (a) Progress curve for $\mathrm{P} 3$ formation during pepsin hydrolysis at $37^{\circ} \mathrm{C}$, $\mathrm{pH}=2$; (b) progress curve for $\mathrm{P} 1$ and $\mathrm{P} 2$ formation during pepsin hydrolysis at $37^{\circ} \mathrm{C}, \mathrm{pH}=2$.

\section{Trypsin Degradation of Whey Proteins and Peptide Formation}

HT using pH 8 and 9 at $37^{\circ} \mathrm{C}$ presented similar profiles (Fig. 4a); $\alpha$-la degradation after $15 \mathrm{~min}$ was almost complete. Trypsin degraded $\beta$-lg, leaving about $30 \%$ intact after $5 \mathrm{hr}$ of incubation. As expected, a temperature increase to $50^{\circ} \mathrm{C}$ resulted in an increase of $\beta$-lg degradation (Fig. 4b). Hydrolysis with trypsin led to the formation of a large number of peptides with higher ranges of polarities than pepsin hydrolysis (Fig. 5). After 60 min of hydrolysis, a significant part of the $\beta$-lg had disappeared and nine major peaks were observed in the chromatogram (Fig. 5). The retention times for the nine major peaks, designated from $\mathrm{T} 1$ to $\mathrm{T} 9$ in order of increasing times, were 9.3, 18.8, 22.4, 23.6, 25.9, 26.5, 27.9, 29.4, and 31.7, respectively. 

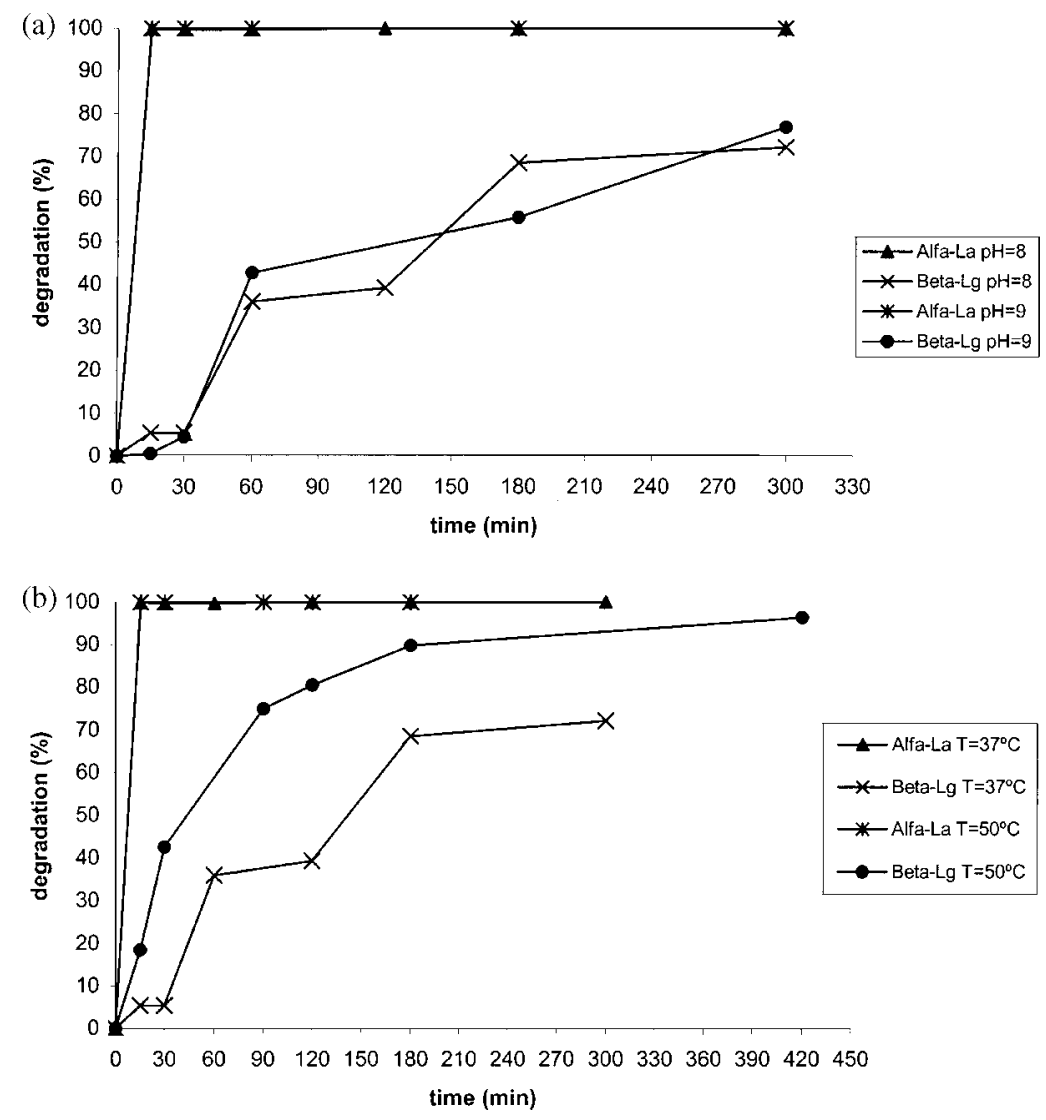

Figure 4. (a) Evolution of $\beta$-lg and $\alpha$-la degradation during trypsin hydrolysis at $37^{\circ} \mathrm{C}, \mathrm{pH}=8,9$, and 4 ; (b) $\mathrm{pH} 8$ at 37 and $50^{\circ} \mathrm{C}$.

The relative areas of these degradation products increased on further hydrolysis up to $5 \mathrm{hr}$. Good chromatographic separation was obtained. Figure 6 shows peptide formation during hydrolysis, peak areas are given in percent of peak area of initial $\beta-\lg$.

\section{Alcalase ${ }^{\circledR}$ Degradation of Whey Proteins and Peptide Formation}

Alcalase ${ }^{\circledR}$ rapidly hydrolysed $\alpha$-la and $\beta$-lg at $37^{\circ} \mathrm{C}$ using $\mathrm{pH} 7,8$, and 9 (Fig. 7a), the same occurred at $\mathrm{pH}=8$ and $\mathrm{T}=37$ and $50^{\circ} \mathrm{C}$ (Fig. $7 \mathrm{~b}$ ). 


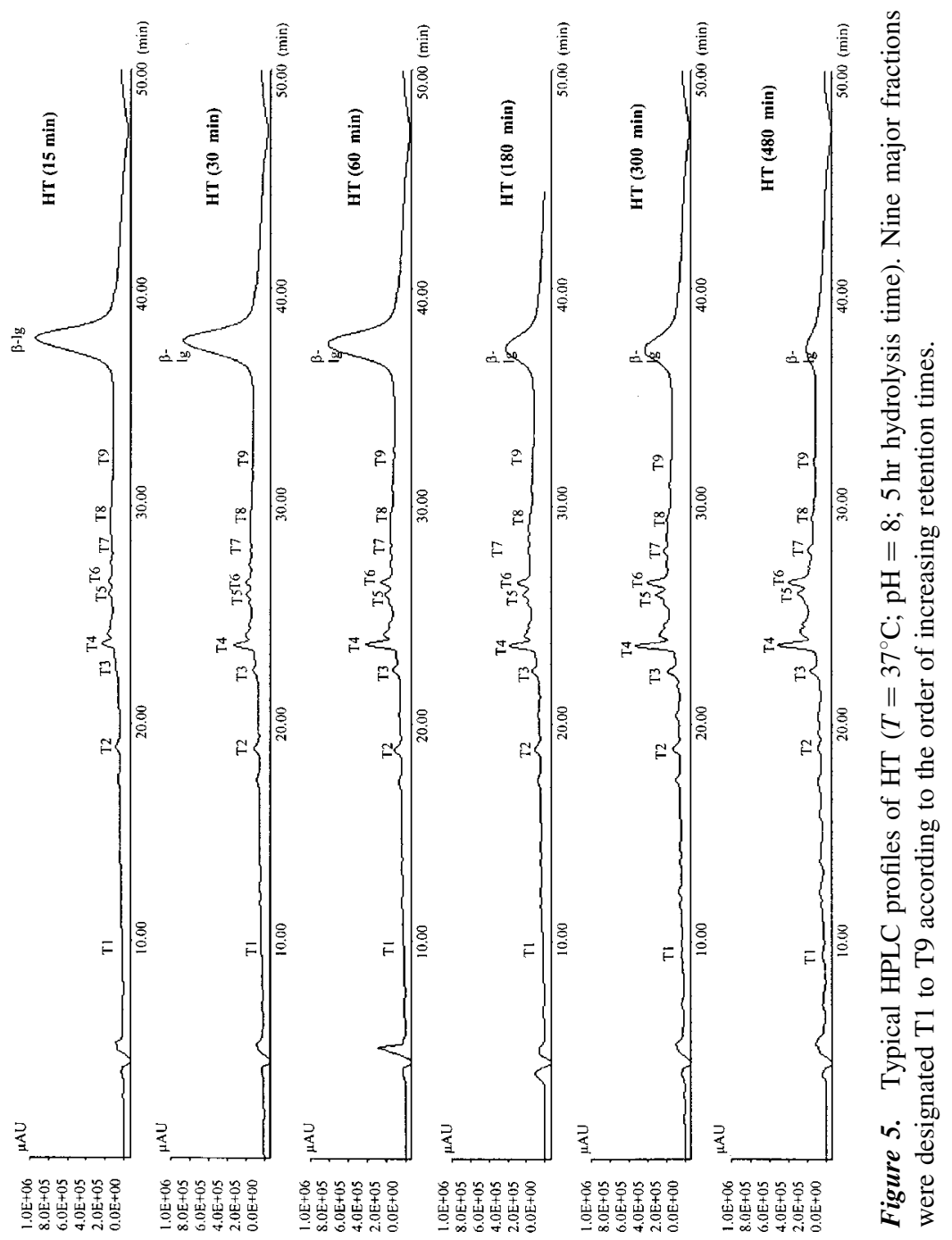




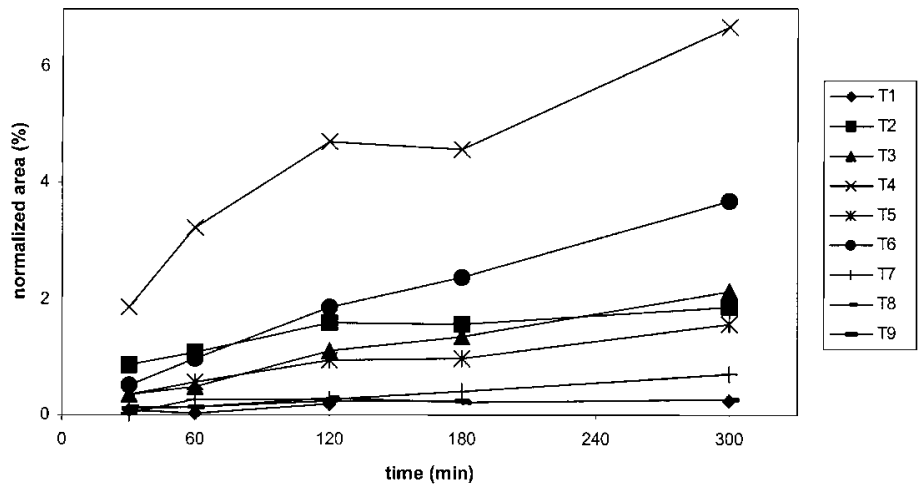

Figure 6. Progress curves for peptide formation during trypsin hydrolysis at $37^{\circ} \mathrm{C}$, $\mathrm{pH}=8$.
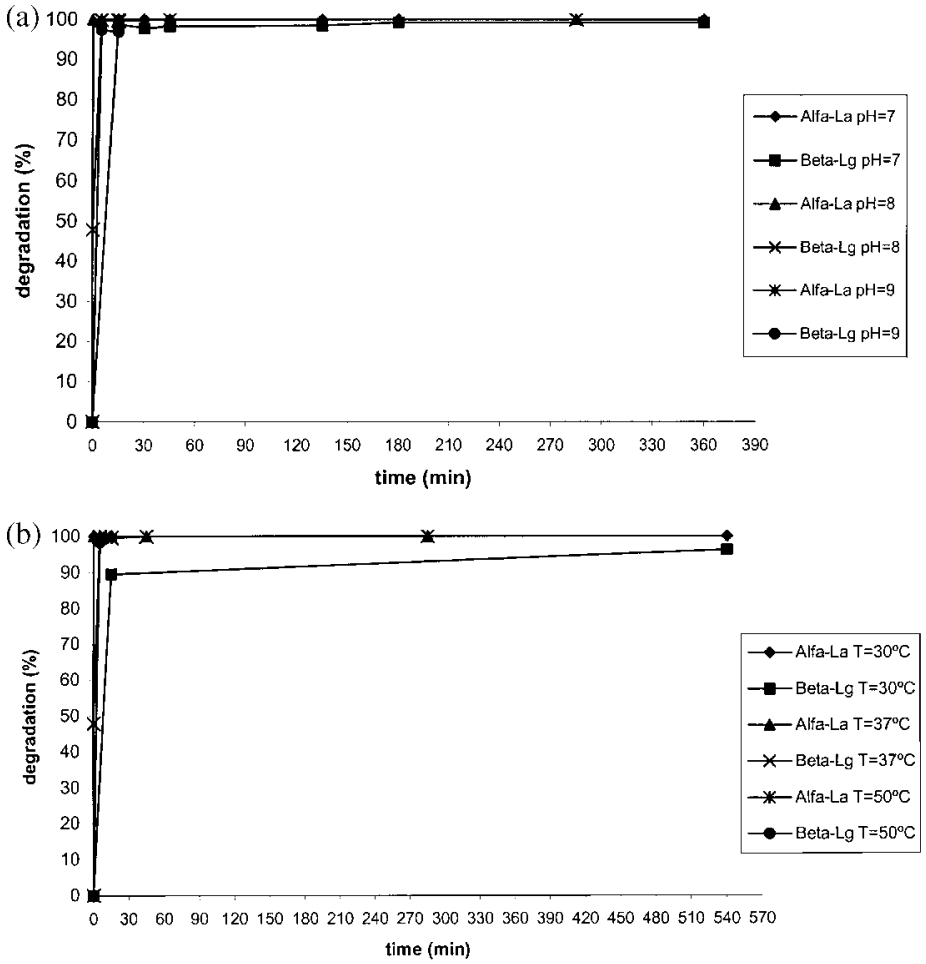

Figure 7. (a) Evolution of $\beta$ - $\lg$ and $\alpha$-la degradation during $\mathrm{HA}$ at $37^{\circ} \mathrm{C}, \mathrm{pH}=7,8$, and 9 ; (b) $\mathrm{pH} 8$ at $30^{\circ} \mathrm{C}, 37^{\circ} \mathrm{C}$, and $50^{\circ} \mathrm{C}$. 


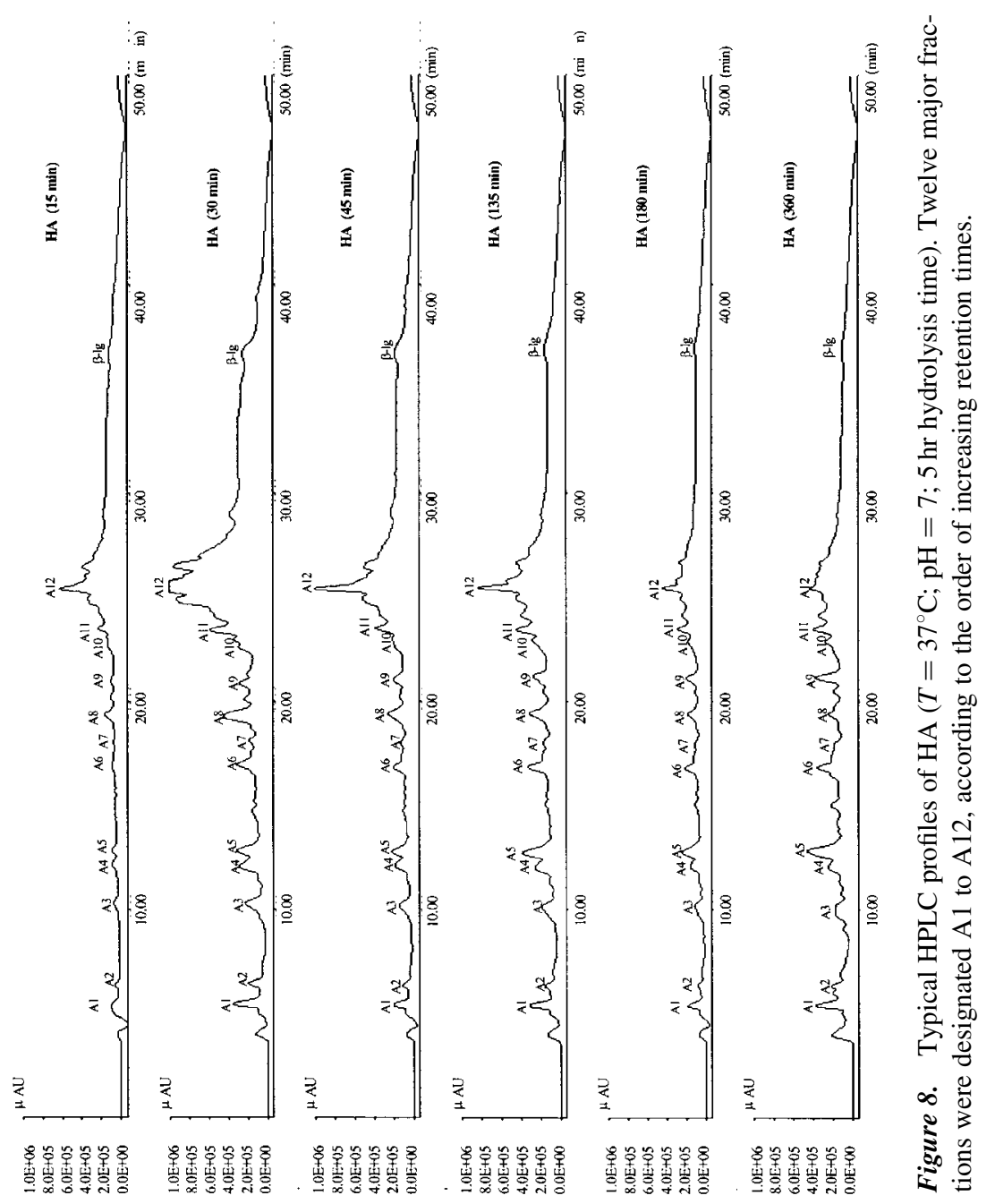



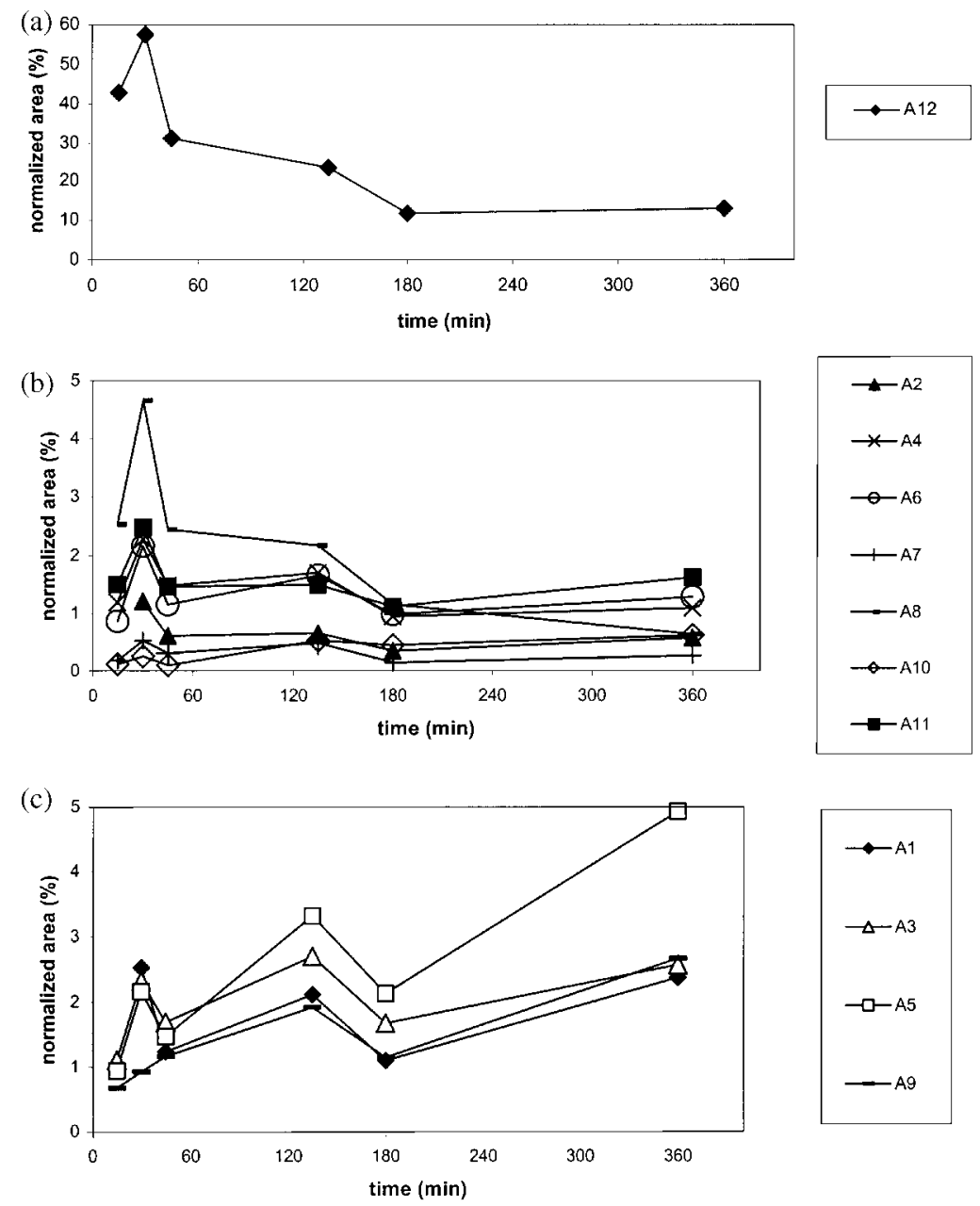

Figure 9. (a) Progress curves for $\mathrm{A} 12$ formation during $\mathrm{HA}$ at $37^{\circ} \mathrm{C}, \mathrm{pH}=7$. (b) Progress curves for A2, A4, A6, A7, A8, A10, and A11 formation during HA at $37^{\circ} \mathrm{C}, \mathrm{pH}=7$. (c) Progress curves for $\mathrm{A} 1, \mathrm{~A} 3, \mathrm{~A} 5$, and $\mathrm{A} 9$ formation during $\mathrm{HA}$ at $37^{\circ} \mathrm{C}, \mathrm{pH}=7$.

At $30^{\circ} \mathrm{C}$, hydrolysis of $\beta$-lg was slightly slower. Alcalase ${ }^{\circledR}$ hydrolysis (HA) resulted in the appearance of 12 major peptide fractions on the HPLC chromatogram with a wide range of polarities (Fig. 8). Alcalase ${ }^{\circledR}$ enzymatic cleavage led to the hydrolysis of $\alpha$-la and $\beta$-lg and formation of transitory peptides, that suffered further hydrolysis (Fig. 9a-c). 


\section{CONCLUSIONS}

The three proteolytic enzymes (pepsin, trypsin, and Alcalase ${ }^{\circledR}$ ) employed for hydrolysis of WPCs led to different kinetics of degradation $\beta$-lg. $\alpha$-la degradation, after $15 \mathrm{~min}$, was almost complete for the three enzymes.

The chromatographic technique developed has proven to be adequate for the study of chromatographic profiles of the hydrolysates. Different RP-HPLC/UV finger print profiles were obtained for the hydrolysates of pepsin, tripsin, and Alcalase ${ }^{\circledR}$. Pepsin hydrolysis led to the formation of three major peptide fractions of high polarity, while HT were resolved into nine major peaks and HA were resolved into 12 major peaks, presenting a wide range of polarities and sizes.

\section{ACKNOWLEDGMENT}

This work received financial support from Fundação para a Ciência e a Tecnologia (project POCTI/2000/QUI/36452).

\section{REFERENCES}

1. Korhonen, H. Technology options for new nutritional concepts. Int. J. Dairy Technol. 2002, 55 (2), 79-88.

2. Clare, D.A.; Swaisgood, H.E. Bioactive milk peptides: a prospectus. J. Dairy Sci. 2000, 83, 1187-1195.

3. FitzGerald, R.J.; Meisel, H. Milk protein-derived peptide inhibitors of angiotensina-I-converting enzyme. British J. Nut. 2000, 84 (1), S33-S37.

4. Shah, N.P. Effects of milk-derived bioactives: an overview. British J. Nut. 2000, 84 (1), S3-S10.

5. Leppala, A.P.; Rokka, T.; Korhonen, H. Angiotensin I converting enzyme inhibitory peptides derived from bovine milk proteins. Int. Dairy J. 1998, $8,325-331$.

6. Silvestre, M.P.C. Review of methods for the analysis of protein hydrolysates. Food Chem. 1997, 60, 263-271.

7. Foegeding, E.A.; Davis, J.P.; Doucet, D.; McGuffey, K. Advances in modifying and understanding whey protein functionality. Trends Food Sci. Technol. 2002, 13, 151-159.

8. Madsen, J.S.; Ahmt, T.Ø.; Otte, J.; Halkier, T.; Qvist, K.B. Hydrolysis of $\alpha$-lactoglobulin by four different proteinases monitored by capillary electrophoresis and high performance liquid chromatography. Int. Dairy J. 1997, 7, 399-409. 
9. Chen, S.X.; Swaisgood, H.E.; Foegeding, E.A. Gelation of $\beta$-lactoglobulin treated with limited photeolysis by immobilized trypsin. J. Agric. Food Chem. 1994, 42, 234-239.

10. Otte, J.; Ju, Z.Y.; Faergemand, M.; Lomholt, S.B.; Qvist, K.B. Proteaseinduced aggregation and gelation of whey proteins. J. Food Sci. 1996, 61 (5), 911-915.

11. Otte, J.; Zakora, M.; Qvist, K.B.; Olsen, C.E.; Barkholt, V. Hydrolysis of bovine $\alpha$-lactoglobulina by various proteases and identification of selected peptides. Int. Dairy J. 1997, 7, 835-848.

Received April 12, 2004

Accepted April 30, 2004

Manuscript 6389 